\title{
GENDER BASED ANALYSIS OF SOCIAL AND ECONOMIC CONDITIONS OF CHILD LABOURERS LIVING IN KARACHI
}

\author{
Nasreen Aslam Shah* \\ Rashid Iqbal $^{* *}$ \\ Aamir ul Haque ${ }^{* * *}$
}

\begin{abstract}
This study aims to draw a gender based analysis of social and economic conditions of child labourers living in Karachi. Globally the issue of child labour is growing constantly and children are engaged in all sorts of hazardous forms of work, like adults, which deprives them from education, healthy life, child hood activities and balanced diet. In Pakistan the child labour is very common in all economic sectors, but it is mainly found in the informal sector and the household sector. Purposive and convenience sampling techniques of non-probability sampling are used to collect data through structured questionnaire from 900 respondents from eighteen (18) administrative districts of Karachi, which is based upon primarily quantitative and narrowly focused qualitative research methods. The findings of the study reveal that mostly children between the ages of 12 to 14 years are commonly inducted in different economic sectors. This clear violation of child rights makes them vulnerable to health and safety threats and putting them forcefully in hazardous occupations to earn bread and butter for their family by compromising their education.
\end{abstract}

Keywords: Child labour, poverty, health, social and economic conditions, gender, education

\section{Introduction}

The issue of child labour is very common all over the world, especially in the third world countries. It is more prevalent in rural areas because enforcement of age limit is not applicable there, but it is found in both urban and rural areas. If the children are forced to work in their youth years then their future will be at stake and can be easily exploited due to extreme poverty and they work under hazardous conditions on low paid jobs, but they still contribute in their family income. ${ }^{1}$ The most apparent economic pressure of child toils at the household level is the intensification in domiciliary expenses. In the long term, decline in child education, low school turnout and poor well-being is a serious and negative outcome of child labour. Child labourers evolve to become low-income earners in their future, which results in their progenies and are forced to earn for their families,

\footnotetext{
* Nasreen Aslam Shah, Ph.D. Meritorious Professor, Department of Social Work \& Director, Centre of Excellence for Women's Studies, University of Karachi.

${ }^{* *}$ Rashid Iqbal, Ph.D Scholar, Centre of Excellence for Women's Studies, University of Karachi.

${ }^{* * *}$ Aamir U1 Haque, Ph.D Scholar, Centre of Excellence for Women's Studies, University of Karachi.

${ }^{1}$ Attri, Dr. Ajay Kumar. Indian Initiatives Against Child Labour, International Journal of English and Education, 2014, Vol. 3(2), Available at http://ijee.org/ yahoo_site_admin/assets/docs/ 54.87130202.pdf.
} 
and this compulsive child labour extends the poverty to many future generations. ${ }^{2}$ Due to uncertain economic conditions child labour is a compulsion, but it is a disturbing factor when they do economic activity at the cost of their education and their future. ${ }^{3}$ It is a form of slavery which binds children in its vicious cycle and in some cases children are forced to live away from their family. Working under extreme conditions and stress child faces physical and mental harm, abusive behaviour of their employer and senior coworkers. ${ }^{4}$ Any sort of work that renders a child in trouble, abuse and exploitation is called child work. ${ }^{5}$ Children start working at an early age, which denies their rights of having a joyful childhood. Private sector, organizations and other stakeholders can put their input in reducing child labour and improving the hazardous working conditions to avoid work related injuries. It is very important to realize the severity to stop the practice of hiring children in dangerous forms of work. Every child has the basic right to get appropriate treatment from the society and the employer. ${ }^{6}$ In the past two decades, this problem has gained the attention of media, governments, international community and the civil societies.

The ILO demands that child labour is constantly unlawful and expresses it as follows:

1. The economic activities of children under the age of 12;

2. A light labour, completed by children aged 12 to 14 ;

3. The horrendous type of child labour, regardless of the age of children. ${ }^{7}$

Child labour is rooted in poverty and is often accompanied by multiple complexities along with the social and economic differences founded on linguistic, ethnic, infirmity and rural-urban grounds, which are still deeply ingrained. ${ }^{8}$ Therefore, gender is a key determinant when children are involved in workforce. Whereas, child labour violates the constitutional rights of all children both boys and girls, especially girls, because they tend to instigate work earlier than boys, particularly in rural zones or wherever the majority of toiling children is found. Girls seems to be performing more work at home than boys. ${ }^{9}$ Since society observes socially constructed gender roles, therefore several girls are deprived of the right to receive education, and have to do domestic chores. Besides

${ }^{2}$ Verma, A. Child Labour: The effect on Child, International Journal of Advanced Educational Research, (2018). Vol. 3(1), pp. 83-86

${ }^{3}$ Attri, Op.cit.

${ }^{4}$ Sharma, Usha (Ed.). Child labour in India,(New Dehli, India: Krishan Mittal for Mittal Publications, (2006), p.173

${ }^{5}$ International Labour Office \& InFocus Programme on Promoting the Declaration. (2001). Work in freedom: Declaration on fundamental principles and rights at work, Geneva, ILO.

${ }^{6}$ International Labour Organization (ILO). Employers and Child Labour. Guide 1: Introduction to the Issue of Child Labour, (Switzerland: International Labour Office, Geneva, 2007), p.4

${ }^{7}$ Edmonds, E.V. (2009). Defining Child Labour: A Review of the Definition of Child Labour in Policy Research, Geneva, International Labour Organization, p.1

${ }^{8}$ International Labuor Organization (ILO). IPEC: World Day Against Child Labour (2009): Give girls a chance, ILO(2009).

${ }^{9}$ International Labuor Organization (ILO). Child labour: Targeting the intolerable. International Labour Conference, 86th Session 1998, Report V, Geneva, (1998), p.123, ISBN: 92-2-

110328-5. Available at: https://resourcecentre.savethechildren.net/sites/default/files/ documents/2622.pdf 
domestic responsibilities girls get engaged in both paid and unpaid work. ${ }^{10}$ Normally girls are involved in domestic chores to help out their families even more than boys. This hard work comprises of baby-sitting, preparing food, cleaning and etc. Girls are not only engaged in domestic work, in fact, they also bear the triple burden. ${ }^{11}$ This might have a harmful influence on any schooling opportunities and may pose a physical threat to girls. Children who work as child labourers are frequently neglected and are very unfortunate for not having a normal life like privileged children. ${ }^{12}$ They contribute in their family's economic survival by becoming packers, housekeepers, employees of factories, or as street vendors. These children are generally subject to fierce exploitation by their illegal employers, for example through low wages for long working hours, manual labour that is not suitable for their fragile and young age, and working conditions, which puts the health, physical and mental growth at stake. These children are normally exploited by their employers very conveniently by depriving them from proper balanced diet and proper sleep, by treating them as slaves at work place, or even worse than that is they are beaten up brutally. ${ }^{13}$

There are numerous types of child labour throughout the world like agrarian workforce, mining, manufacturing, construction, caretaker, sweepers and begging. Many children are hired as bonded labours to pay off the debts of their parents. ${ }^{14}$ Children working in the informal sector are not even paid for any injuries or illness caused by work, and if they are subjected to violence or abuse by the employers even then they do not get protection of any sort. ${ }^{15}$ Generally, just like global trends child labour is common in lower class families not only in Pakistan but also in other countries of South Asia as well. Current studies show that poverty plays its role in incorporating children into the labour force and that the parents are not serious about educating their children, especially girls. ${ }^{16}$ Researches also confirm that poverty is an important contributing factor in child labour, but it does not prohibit children from going to school. ${ }^{17}$ According to the studies, children are dropping out of schools in countries like India, Bangladesh and Pakistan constitutes half of the child labour force in the world. ${ }^{18}$ In Pakistan and other developing countries, children of poverty-stricken families have the tendency to work at a young age and

${ }^{10}$ Ilahi, Nadia. The intra-household allocation of time and tasks: What have we learnt from empirical literature? Policy Research Report on Gender and Development, Working Paper Series No. 13, (Washington, D.C.: World Bank, 2001), p. 48

${ }^{11}$ International Labuor Organization (ILO). IPEC: World Day Against Child Labour (2009): Give girls a chance, ILO (2009).

${ }^{12}$ Luke, Helesia \& Moore, Grane. Who's Looking Out for our Kids? Deregulating Child Labour Law in British Columbia, (Canada: Canadian Centre for Policy Alternatives-BC Office, 2004), p.4

${ }^{13}$ Ibid.

${ }^{14}$ U.S Dept. of Labor. Findings on the Worst Forms of Child Labor, (US: Bureau of International Labor Affairs, 2004), p. 484

${ }^{15}$ International Labour Organization Child Labour: A textbook for university students, (Geneva: International Labour Organization, 2004), p.23

${ }^{16}$ Hindman, H.D. The World of Child Labor: An Historical and Regional Survey, (New York: Routledge, 2009), p.769

${ }^{17}$ Galli, Rossana. The Economic Impact of Child Labour, (Geneva: International Institute for Labour Studies, 2001), p.1

${ }^{18}$ Fyfe, A. Child Labour Policy Option, (Amsterdam: Aksant Academic Publishers, 2004), p.80 
usually have the lowest education level and other social plights. ${ }^{19}$ Rendering to the estimates of the ILO (2008) Pakistani Child Labour Survey clearly shows that almost 8.3 $\%$ of the total child labourers, i.e. 3.3 million, out of 40 million between the ages of 5 to 14 years are in numerous professions on permanent basis in Pakistan's formal and informal sector. ${ }^{20}$ Though Pakistan has child labour laws, but they are not implemented properly. The child labourers are easily exploited to the extreme levels even, and deprive them from having their livelihood. On the other hand, some researches have concluded that child labour is increasing poverty, unemployment and hampers children in many other exploitative paradigms. Therefore, the present study has strictly focused on the gender based analysis of social and economic conditions of child labourers living in Karachi.

\section{Objectives}

This study has the following specific objectives:

- To understand social and economic factors under which these children live and work

- To find out the level of change occurring in the family due to their work

- To know the contributing factors of child labour

- To know the causes of their work

- To know the working environment of children

- To find out the income of working children from various professions

\section{Theoretical Framework}

The basic and fundamental theories are developed on the basis of demand and supply factors and the theory of human capital. Various theories have been established to provide a research based analytical source that, how these theories are pragmatic empiricists and can provide the foundation for analysis? The human capital theory analyzes the fundamental relationship between poverty and the child work in Pakistan's existing social and economic scenario. In contrast, rapid population growth, redundancy, migration from one place to another, poverty and the system of education centered poor living have appeared as contributing factors in regard to child labour. Employing children is a means of hiring cheap labour force, who can work under unfavorable conditions without complaining. Among many other theories the Human Capital Theory (HCT), is a verification regarding the neoclassical examination of the market, education, and the financial escalation. According to Tharenou and Brennan, the human capital theory believes that people are productive capitals and that people with higher education are more fruitful than others. From this point of view, education denotes investment in human capital, which can be vindicated on the basis of improved proficiency and improved productivity. ${ }^{21}$ Improved and enhanced skill and education can reduce poverty and child labour and it guides towards the

${ }^{19}$ Mazhar, Zaigham. Child Labour in Pakistan: Including the Excluded, (Latvia: Lap Lambert Academic Publishing GmbH KG, 2012), p. 52

${ }^{20}$ International Labour Conference. Skills for improved productivity, employment growth and development, (Geneva: International Labour Office, 2008), p.80

${ }^{21}$ Tharenou, P., Saks, M. \& Moore, C. A Review and Critique of Research on Training and OrganisationalLevel Outcomes, (Human Resource Management Review, 2007), vol.17, pp. 251-273 
economic transformation. Throughout the growth period, human capital theory was used to clarify the economic principles of individuals investing in education, nutrition, and health. However, it has been refined and it has now turned from microscopic to macroscopic. ${ }^{22}$ The basic conflict is that the human capital frills the investment, technological, physical and social development, it also focuses on investing in education to produce better and skilled labour force. ${ }^{23}$ The findings of various studies highlight the fact that if the family income is low and the schooling expenses are higher, then poor families cannot afford to send their children to school even if they want to. Jensen and Nielsen argue that the theory of human capital is not an appropriate theory to explain the features of the child's work and income; they find it effective in regard to child labour. ${ }^{24}$

\section{Literature Review}

Children are considered as an asset for any nation for future benefits and human development; therefore, favourable social conditions and possibilities of a better future should be provided to them so that they can reach to their full potential growth, psychological and social development. Moreover, their better life along with better education opportunities can make them useful for the country in the future. Economic activities at such an early age make their future shaky and uncertain. Poverty not only deprives children from getting education, but also puts their life and bright future at stake. Low self-esteem, exploitative working conditions, the bad behaviour of an employer and exploitation are the outcomes of work at an early age. ${ }^{25}$

Child labour cannot be abolished completely, but its severity can be reduced by abolishing its worst forms. Child labour is still not properly defined at any forum of international level; therefore, there is no standard process and strategy to counter the issue. For this purpose international agreements and strategies should be developed and all of the nations should agree on the universality of an issue to address this social evil appropriately. $^{26}$ On the other hand, few researches claim that with all these apprehensions child labour has some bounties to offer as well, i.e. skills enhancement, economic independence, confidence and learning socialization techniques. ${ }^{27}$ According to studies, child labour is not an issue, it is in fact the hazardous working conditions under which they have to perform their economic activities. ${ }^{28}$ As per historical facts child labour gained prominence after the world wars, when development and economic growth became the main focus of governments for gaining prosperity through

${ }^{22}$ International Labour Organization, Sub-Regional Information System on Child Labour, (IPEC, 2008). Available at http://www.ilo.org/public/english/ region/asro/newdelhi/ipec/Responses/pakistan/index.htm, Retrieved on $25^{\text {th }}$ January 2017

${ }^{23}$ Economist Newspaper Limited, The Economist, (2001), Vol. 360, p. 233

${ }^{24}$ Jensen, P. \& Nielsen, H. Child Labour or School Attendance? Evidence from Zambia, Journal of Population Economics, (1997), Vol. 10(4), pp, 407-427

${ }^{25}$ Wal, S. Combating child labour: Legal approach, (New Delhi: Sarup \& Sons, 2006), p.276

${ }^{26}$ Nanjunda, D. C. Child labour and human rights: A prospective, (Delhi: Kalpaz Publications, 2008), pp.54,64

${ }^{27}$ Collins, J.L. Fertility Determinants in a High Andes Community, Population and Development Review, (1983), Vol.9:1, pp.61-75

${ }^{28}$ Boyden, J. Working Children in Lima, Peru, In W.E. Myers (ed.), Protecting Working Children. London, Zed Books Ltd in association with UNICEF (United Nations Children's Fund, 1991) 
industrialization, but it actually has its roots in servitude in a variety of forms, ${ }^{29}$ its beginning was recognized officially after the world wars, at that time. ${ }^{30}$ The worst thing about child labour is the risk involvement regarding the health and exploitation of children, which deprives them from having a normal life like other children of the society. ${ }^{31}$ After the realization of the severity of this issue, debate started to improve the working conditions, but nothing fruitful came up in order to resolve the issue. The reasons of child labour remained invisible and it was felt that it is not an easy task to abolish child labour. As per findings, it seems that ignorance on the issue was an intentional and calculated act. Children are usually hired in all forms of work regardless of their age and physical strength, which hampers their physical and mental growth. ${ }^{32}$

In third world countries like Pakistan a large number of children get engaged in income generating programmes to support their families. ${ }^{33}$ Usually children are involved in informal form of work like housekeeping, domestic helper and serves as part-time or fulltime workers. They are also incorporated in industries, shops, hotels, restaurants or as street vendors. ${ }^{34}$ Since Pakistan's economy is mainly based on agriculture. Therefore, the majority of children, i.e. $67 \%$ children work in rural areas and $11 \%$ of the children are incorporated in industries. ${ }^{35}$ The worst form of child labour is seen in brick industry and farming sector. Usually children work in these sectors as bonded labour to pay off the debts taken by their parents. ${ }^{36}$

According to the sociologists the prosperity and future progress of the region is dependent on educated and civilized youth. ${ }^{37}$ Socialization and better living conditions along with access to education and resources assures the secure future of a child. ${ }^{38}$ Child labour is more extensive in the informal economic sector, which is why it remains hidden from the statistical and the strategies setup of the society. ${ }^{39}$ In developing nations child labour appears as unavoidable means of generating family income. Poverty reduction

${ }^{29}$ History of child labour, Available at http://www.buzzle.com/ articles/history-of-child-labor.html, Retrieved on August 4, 2014

${ }^{30}$ E. P., Thompson. The Making of the English Working Class, (London: Penguin, 1968), p.366

${ }^{31}$ Ibrahim, Abdalla \& Abdelgadir, Jihad. Child Labor and Health: A Systematic Literature Review of the Impacts of Child Labor on Child's Health in Low and Middle Income Countries, Journal of Public Health, 2018, pp. 1-9

${ }^{32}$ Kleinberg, S. J. Widows and orphans first: The family economy and social welfare policy: 1880-1939, (Urbana, u.a.: Univ. of Illinois Press, 2006), p.45

33 Jatsun (2018). Child Labour in Pakistan, http://kokein.com/en/child-labor-in-pakistan/, Retrieved on $30^{\text {th }}$ March 2018

${ }^{34}$ Society for the Protection of the Rights of the Child (SPARC) (2015). Child Labour, Available at http://www.sparcpk.org/2015/Child labor.html, Retrieved on 29 ${ }^{\text {th }}$, April 2017.

${ }^{35}$ International Labour Organization (1997). Summary Results of Child Labour Survey in Pakistan, Available at, http://www.ilo.org/wcmsp5/groups/public/---asia/---ro-bangkok/---sro-new_delhi/documents/publication/ wcms_436435.pdf, Retrieved on $3^{\text {rd }}$, May 2015.

${ }^{36}$ Bergner, J. T. Country Reports on Human Rights Practices for 2006, (Committee on Foreign Relations, 2008), Vol. II, p. 2462

${ }^{37}$ Wankel, Charles. Encyclopedia of Business in Today's World, (New York: SAGE Publications, 2009), p.216

${ }^{38}$ Bequele, Assefa \& Boyden, Jo. Combating Child Labour, (Geneva: International Labour Office, 1988), p.44

${ }^{39}$ Jensen, Lene Arnett. The Oxford Handbook of Human Development and Culture, USA, Oxford University Press, 2015), p.57 
techniques and education can eradicate the worst kinds of child labour. ${ }^{40}$ Child labour is the nastiest form of child manipulation. About seventy-three million children belonging to the age group of ten to fourteen years are engrossed in child labour all over the globe. ${ }^{41}$ The illiteracy of the parents, elderly family members, necessity of additional salary and poverty are the chief reasons of the manipulation of child labour. ${ }^{42}$ The pervasiveness of child labour reflects a very unpleasant image of the society, which is not able to stop this social evil. ${ }^{43}$ But in a society where several households may have to strive for the food and survival, the children are forced to work. ${ }^{44}$ Parents have to send their children to work, even if the outcomes of labour work have a negative impact on them, but it seems that it is the only choice left for them to live in this world and it will continue till the socio-economic status of the poor families is enhanced. ${ }^{45}$ A study was done by M.C. Naidu on child labour in India expressed that the core reason which gives intensification to child labour is unemployment especially among the adult labourers. ${ }^{46}$ Another study stated that the industrialization led to a dramatic rise in child labour. Professor Emma Griffin discovered the precarious, fatiguing work undertaken by children in workshops and pitheads. ${ }^{47}$ Jean and James, in their study focued on outcomes of child labour. They further expressed that child labour is increasing due to market defects and trends. ${ }^{48}$ Another research observed that the temporary economic distress also intensifies the activities lead by the child labourers. ${ }^{49}$ Globalization has also raised the prevalence of child labour. Trade theory expects that high cost exports, can diminish child labour to certain extent by reducing its magnitude. This assumption clearly identifies that greater markets can result in decline of child labour. ${ }^{50}$ The economic markets are substandard, thus, providing lesser chances for child education. ${ }^{51}$

In Pakistan child labour started after 1960s as a result of the industrialization concept of boosting economy. ${ }^{52}$ The beginning of the modernization era increased the demand of child labour by employing them in factories at low wages against the maximum work

${ }^{40}$ Rialp, Victoria. Children and hazardous work in the Philippines, (Geneva: International Labor Office, 1993), p.8

${ }^{41}$ Lavalette, Michael. A Thing of the Past? : Child Labour in Britain in the Nineteenth and Twentieth Centuries, (United Kingdom: Liverpool University Press, 1999), p.69

${ }^{42}$ Herath, Gamini \& Sharma, Kishor. Child Labour in South Asia, (England: Ashgate Publishing Limited, 2007), pp.45, 161,162

${ }^{43}$ Gifford, Clive. Child Labour, (London: Evans Brothers Limited, 2009), p.67

${ }^{44}$ Nanjunda, Op.cit., (2008), pp. 54, 64

${ }^{45}$ Nanjunda, D.C. Anthropology and Child Labour, (India: Mittal Publications, 2009), p.33

${ }^{46}$ Naidu, M.C. \& Ramaiah, Dasaratha Child Labor in India- an Overview, (Journal of Social Sciences, 2006), Vol. 13 (3), pp.199-204

${ }^{47}$ Griffin, Emma Childhood and children's literature. (2014), Available at https://www.bl.uk/romantics-andvictorians/articles/child-labour

${ }^{48}$ Baland, Jean- Marie \& Robinson, James A. Is Child Labor Inefficient, Journal of Political Economy, (2000), Vol.108:4

${ }^{49}$ Beegle, Kathleen \& Gatti, Roberts. Child Labor and agricultural shocks, Journal of Development Economics, (2006), Vol. 81 (1), pp.80-96

${ }^{50}$ Edmonds, Eric V. The Effects of trade liberalization on child labor, Journal of International Economics, (2005). Vol.65:2, pp.401-419

51 Udry, Christopher. Child Labor, Economic Growth Center, (Yale University, 2003), Available at http://www.econ.yale.edu/egcenter/ research.html

52 Silvers, J. (1996). Child labor in Pakistan, S.l.: s.n, Available at https://www.theatlantic.com/magazine/archive/1996/02/child-labor-in-pakistan/304660/ 
beyond their capacity, because by hiring children owners gain more profit by cutting the cost and benefits of the labour force. One other reason of hiring children as labour is taking maximum advantage of their innocence, because children are unaware of the business traits and policies, therefore, they are easily exploited and at times they are even sexually abused, especially those kids who live away from home for work. ${ }^{53}$ In 1990, Pakistan became a signatory of United Nation Child Right Commission (UNCRC) under the Article (32), but the child labour still exists and is constantly increasing. Article (32) protects the rights of working children by protecting them from working in hazardous conditions, removing barriers in getting education and in achieving their full potential development. ${ }^{54}$ In Pakistan many laws have been regulated and implemented to curtail children's involvement in economic activities, but still the outcomes of these laws are not very satisfactory. In factories children between the ages 4 to 14 are working under threat of hazardous working conditions. ${ }^{55}$

\section{Methodology}

Methodology is a process which is based on certain approaches and principles for doing something in a proper way. It is the process which is used for accumulating information and figures for the rationale of making final conclusion. ${ }^{56}$ This research study is based upon primarily quantitative and narrowly focused on qualitative research methods which are used to examine the Social and Economic Conditions of Child Labourers Living in a metropolitan city of Karachi. Karachi is the capital of Sindh province and the financial hub of Pakistan, having different ethnic based communities. Though the research is restricted to Karachi only, but it reflects a complete geographical and cultural picture of Pakistan. This research also projects the household poverty, as a main cause of child labour. Therefore, sample is taken from all the 18 administrative districts of Karachi as population for conducting the research. In this research the researcher has used nonprobability method in which purposive and convenience sampling techniques are used to collect data through structured questionnaire from 900 respondents. For this study the interview schedule is structured in Urdu language comprising of 132 open ended and close ended questions so that the respondents can understand question with ease to answer appropriately.

\section{Results and Discussion}

This section contains primarily quantitative and narrowly focused qualitative data and findings followed by discussion.

\footnotetext{
${ }^{53}$ Sattar, Abdul (2008). Child Labour : The Cry of Innocence, Pakistan, p. 36

${ }^{54}$ SPARC (2015). Op.cit.

${ }^{55}$ Herath (2007). Op.cit.

${ }^{56}$ Mouton, Johann \& Marais, H.C. Basic Concepts in the Methodology of the Social Sciences, (South Africa: HSRC Publishers, 1988), pp. 29-30
} 
Table: 1

Distribution of respondents according to the respondents' age

\begin{tabular}{|l|c|c|}
\hline Respondents Age in Years & Frequency & Percentage \\
\hline $6-8$ Years & 26 & $2.83 \%$ \\
\hline $9-11$ Years & 202 & $22.44 \%$ \\
\hline $12-14$ Years & 672 & $74.66 \%$ \\
\hline Total & $\mathbf{9 0 0}$ & $\mathbf{1 0 0 \%}$ \\
\hline
\end{tabular}

According to this table $74.66 \%$ of the respondents which is the largest number fall in the category of 12-14 years of age bracket, while $22.44 \%$ respondents were those who belongs to the age group of 9-11 years and only $2.83 \%$ were from the category of 6-8 years of age group. This clearly identifies that the highest percentage of respondents involved in child labour were in the age group of 12-14 years of age who were engaged in different economic activities. The qualitative analysis supports the findings of the quantitative data where respondents said that they are not only earning bread and butter for their family but also contributing in their family income to fulfil their daily needs. Because of the growing inflation it becomes difficult for them to survive so they have to earn for their family survival and sacrifice their childhood activities for their family.

Table: 2

Distribution of respondents according to their gender

\begin{tabular}{|l|c|c|}
\hline Gender & Frequency & Percentage \\
\hline Boy Child & 774 & $86 \%$ \\
\hline Girl Child & 126 & $14 \%$ \\
\hline Total & $\mathbf{9 0 0}$ & $\mathbf{1 0 0 \%}$ \\
\hline
\end{tabular}

Data has shown that $86 \%$ respondents were boy child, while $14 \%$ were girl child. Data indicated the number of respondents according to their gender who were engaged in different economic activities to supplement their family income for fulfilling their personal needs and the daily needs of their family members. It also indicated that both the genders are involved in supplementing their family income and support their parents but the research findings shows obvious difference between a boy child and a girl child i.e. the income of a boy child is considered more important than of the female child. 
Table: 3

Distribution of respondents according to reason of doing work at early age

\begin{tabular}{|l|c|c|}
\hline Reason & Frequency & Percentage \\
\hline To support their family & 413 & $45.88 \%$ \\
\hline Nobody else earns & 37 & $4.11 \%$ \\
\hline Because of high prices & 288 & $32 \%$ \\
\hline For personal requirements & 74 & $8.22 \%$ \\
\hline For time pass & 63 & $7 \%$ \\
\hline Eldest in the family & 13 & $1.44 \%$ \\
\hline For siblings school fees & 8 & $0.88 \%$ \\
\hline Helping father in earning income & 3 & $0.33 \%$ \\
\hline To learn and develop technical skills & 1 & $0.11 \%$ \\
\hline Total & $\mathbf{9 0 0}$ & $\mathbf{1 0 0 \%}$ \\
\hline
\end{tabular}

Telling about the reasons of doing work at early age $45.88 \%$ said they were supporting their family by doing work, $32 \%$ said because of high prices they cannot manage their daily lives, $8.22 \%$ were stated working to fulfil their personal requirements, $7 \%$ were doing work to keep themselves engage in certain economic activity as a time pass, $4.11 \%$ said that there is no other earning member in their family so they had to start doing work to resolve their economic problems, $1.44 \%$ were the eldest in their family so they take all the economic pressure on them for the sake of their family, while $0.88 \%$ started doing work to earn school fees for their siblings, $0.33 \%$ were helping their fathers in earning income for the family, and $0.11 \%$ said they started doing work just to learn and develop technical skills.

In qualitative analysis many of the participants highlighted that they also want to study like other children but their economic conditions and the nature of work do not allow them to study and they work to support their parents. These children are working almost in all economic sectors, working as street vendors, workshop mechanics, tailors, making furniture, house maids, plumbers, repairing fridge and air conditioners, ragman, dying clothes etc. just to provide financial support to their family members and become a productive part of the family rather than becoming burden on them. At this age all of them are very sensitive and seems responsible and caring towards their families. 
Table: 4

Distribution of respondents according to who earns more

\begin{tabular}{|l|c|c|}
\hline Who Earns More & Frequency & Percentage \\
\hline Boys & 624 & $69.33 \%$ \\
\hline Girls & 59 & $6.55 \%$ \\
\hline Both & 217 & $24.11 \%$ \\
\hline Total & $\mathbf{9 0 0}$ & $\mathbf{1 0 0 \%}$ \\
\hline
\end{tabular}

While asking them that who earns more $69.33 \%$ respondents said that boys earn more because they work for more hours than girls, $24.11 \%$ said that there is no distinction between both the genders both earns equally whereas $6.55 \%$ said that normally girls earn more than the boys. An in depth analysis shows that both are involved in economic activities but girls are doing more work at home than boys. Due to socially constructed gender roles girls are responsible to look after the domestic affairs, taking care of younger siblings and are deprived of the right of education and have to fulfil their responsibilities. Girls are also engaged in doing work outside the home. They perform both paid and unpaid work along with their mothers who are working as maids.

Table: 5

Distribution of respondents according to their personal Monthly income in Pak. Rupees

\begin{tabular}{|l|c|c|}
\hline Personal Monthly Income in Pak. Rupees & Frequency & Percentage \\
\hline $1000-3000$ & 449 & $49.88 \%$ \\
\hline $3001-5000$ & 245 & $27.22 \%$ \\
\hline $5001-7000$ & 80 & $8.88 \%$ \\
\hline More than 7000 & 126 & $14 \%$ \\
\hline Total & $\mathbf{9 0 0}$ & $\mathbf{1 0 0 \%}$ \\
\hline
\end{tabular}

About $49.88 \%$ respondents said that they were earning in 1000-3000 Rs. per month, $27.22 \%$ were in the bracket of 3001-5000 Rs. per month, whereas $8.88 \%$ each said that they were earning in between 5001-7000 per month and 14\% replied that they were getting more than $7000 \mathrm{Rs}$. per month to meet their daily basic needs.

Majority of the respondents explained that normally they get payment on daily basis there are few who said that they get salary on monthly basis. Some of them said that they get payment on weekly basis whereas only $0.77 \%$ said that they get salary after completion of work. This shows the trend that all these children who are engaged in doing work are not the permanent employees they can easily be fired by their employer at any time 
without any prior notification. They all are underpaid and even they are not getting the minimum wage which is $15000 /$ - Rs. per month according to the budget 2017-18 set by the Government of Pakistan. All of them are doing under paid jobs just for the sake of their survival.

Table: 6

Distribution of respondents according to is their income sufficient to fulfils their family expenses

\begin{tabular}{|l|c|c|}
\hline Fulfils family expenses & Frequency & Percentage \\
\hline Yes & 315 & $35 \%$ \\
\hline No & 585 & $65 \%$ \\
\hline Total & $\mathbf{9 0 0}$ & $\mathbf{1 0 0 \%}$ \\
\hline
\end{tabular}

Data reveals that $65 \%$ respondents said that their income is not enough to meet the day to day basic needs, whereas 35\% said they are happy with what they are earning and their income contributed in house income to meet the daily needs respectably.

Qualitative analysis shows that majority of the respondents are not satisfied with what they are earning because their limited income is not sufficient to meet their daily needs and some of them are doing some other work as well to supplement their income. Majority of them also said that their other family members are also doing work to fulfil their basic daily needs. The fulfilment of daily needs vary from family to family depending on their expenses and size of the family.

Table: 7

Distribution of respondents according to, are they getting education

\begin{tabular}{|l|c|c|}
\hline Are You getting Education & Frequency & Percentage \\
\hline Yes & 276 & $30.66 \%$ \\
\hline No & 624 & $69.33 \%$ \\
\hline Total & $\mathbf{9 0 0}$ & $\mathbf{1 0 0 \%}$ \\
\hline
\end{tabular}

When asked the respondents about their education $69.33 \%$ said that they are not getting education while $30.66 \%$ of the respondents were those who reply in yes that along with their work they are also getting education.

Qualitative analysis supports this view that unstable socio-economic status becomes hurdle in getting education, due to bad economic conditions majority of children get engaged with different types of work to fulfil their basic needs and do not get time for education although they have a desire to go to school and study like other children. Some 
respondents have explained that out of their busy work schedule they somehow manage to take out some time for their studies. They also said that there are some social workers in Karachi who opened up street schools in the evening for those children who cannot afford the school fees or who are engaged in doing some economic activities and cannot go to school so they go there and spend some time in learning activities.

Table: 8

\section{Distribution according to if no then have they ever get education}

\begin{tabular}{|l|c|c|}
\hline If No then have You ever get Education & Frequency & Percentage \\
\hline Yes & 281 & $45.03 \%$ \\
\hline No & 343 & $54.96 \%$ \\
\hline Total & $\mathbf{6 2 4}$ & $\mathbf{1 0 0 \%}$ \\
\hline
\end{tabular}

While asking the respondents that have they ever get education $54.96 \%$ said that they never get education while $45.03 \%$ respondents said that they were getting education but due to their work they quit and engaged in earning for their family members.

In qualitative analysis, many respondents highlighted that economy is the major factor which creates hurdles in the way of their education. If they or their parents have money, they will spend it on their education. But in this regard awareness should be there because some respondents are unaware of the importance of education. According to them education has no value and people do not get job without any source and get frustrated even after having a degree. They think that they are better than those educated people who have a degree but do not have a job whereas they do not have a degree but they are engaged in economic activity and supporting their family rather than becoming a burden on their parents.

Table: 9

Distribution according to if yes then what is the reason tor giving up education

\begin{tabular}{|l|c|c|}
\hline Reasons & Frequency & Percentage \\
\hline Economic crisis & 104 & $37.01 \%$ \\
\hline Domestic problems & 110 & $39.14 \%$ \\
\hline No interest in education & 67 & $23.84 \%$ \\
\hline Total & $\mathbf{2 8 1}$ & $\mathbf{1 0 0 \%}$ \\
\hline
\end{tabular}

Data has shown that $39.14 \%$ respondents said they give up their education because of their domestic problems, $37.01 \%$ gave up their education due to the economic instability and $23.84 \%$ respondents were not interested in getting education at all. The research findings shows that poverty and other factors related to poverty deprives children from 
getting education and due to poor economic conditions they are forced to earn for themselves and for their families.

Table: 10

Distribution of respondents according to if there is any difference in the diet plan of girls and boys at home

\begin{tabular}{|l|c|c|}
\hline $\begin{array}{l}\text { Any difference in the diet plan of a Girls } \\
\text { and Boys at home }\end{array}$ & Frequency & Percentage \\
\hline Yes & 35 & $3.88 \%$ \\
\hline No & 865 & $96.11 \%$ \\
\hline Total & $\mathbf{9 0 0}$ & $\mathbf{1 0 0 \%}$ \\
\hline
\end{tabular}

When asked them if there is any difference in the diet of girls and boys $96.11 \%$ said there is no difference because they cook only one dish at a time so everyone has to eat the same food as they cannot afford to cook more dishes or according to the everyone's desire, while $3.88 \%$ said that there is a difference in diet of girls and boys in their home usually boys get the good food and remaining goes to girls because they think that males need more food than girls. These misconceptions have created a huge difference and the girls do not get recommended dietary allowance which is necessary for their potential and reproductive growth.

Table: 11

Distribution according to any significant change occurred in their home due to their work

\begin{tabular}{|l|c|c|}
\hline Any Change Occurred & Frequency & Percentage \\
\hline Yes & 423 & $47 \%$ \\
\hline No & 477 & $53 \%$ \\
\hline Total & $\mathbf{9 0 0}$ & $\mathbf{1 0 0 \%}$ \\
\hline
\end{tabular}

Data reveals that $53 \%$ said that there is no change occurred in their house due to their work because what they were earning in not sufficient but $47 \%$ said some changes occurred that their mother purchases some electronic items by saving this money.

In qualitative investigation majority of the respondents said that they saves nothing so no change occurred in their home, according to them how can a poor bring change, changes only occurred in elites houses where they have lot of money to spend. Those who said that some changes occurred in their house said that they are taking quality food, their living standard improves little bit, their siblings started going to school because they are now paying their school fees from their salary and over all their family health get improves as they are taking proper care of their family members. 
Table: 12

Distribution of respondents according to how much they spend on themselves

\begin{tabular}{|l|c|c|}
\hline Spend on yourself & Frequency & Percentage \\
\hline According to requirement & 558 & $62 \%$ \\
\hline Rs. $10-15$ & 27 & $3 \%$ \\
\hline Rs. $16-20$ & 31 & $3.44 \%$ \\
\hline More than Rs. 20 & 143 & $15.88 \%$ \\
\hline Small amount & 141 & $15.66 \%$ \\
\hline Total & $\mathbf{9 0 0}$ & $\mathbf{1 0 0 \%}$ \\
\hline
\end{tabular}

When asked them how much amount they spend data reveals $62 \%$ said that they spend their income according to the requirement, $15.88 \%$ said that they spend more than 20 Rs. on daily basis, $15.66 \%$ respondents said that they spend very small amount, while $3.44 \%$ spend in between 16-20 Rs., and 3\% used to spend only 10-15 Rs. on them. Detailed analysis shows that majority of them do not spend money on themselves because they save each and every penny of their income for their rainy days and in case of any emergency. They even do not spend it on taking food at work place or for their personal needs. They bring food from their home to save money. Because they cannot afford to have luxuries therefore they are compelled to save whatever they earn. Their type of work and jobs are not permanent and even their wages are not fixed which is why they cannot expend any money to fulfil their personal desires.

Table: 13

Distribution of respondents according to what is the work place environment

\begin{tabular}{|l|c|c|}
\hline What is the Work Place Environment & Frequency & Percentage \\
\hline Good & 810 & $90 \%$ \\
\hline Bad & 90 & $10 \%$ \\
\hline Total & $\mathbf{9 0 0}$ & $\mathbf{1 0 0 \%}$ \\
\hline
\end{tabular}

As per data majority of the respondents (90\%) said that their work place environment is good and $10 \%$ said that work place environment is not good. There is no proper light and air in the work place and hygiene conditions are also not good. Majority of the respondents said that they are working in a good environment and work with ease and feel good while working as their immediate boss treat them nicely. While some respondents said that they are working in an irritating environment and feel uncomfortable during work as their employer treat them strictly. 


\section{Conclusions}

This study explains the socio-economic conditions of the child labour in Karachi on the basis of gender. Major findings of the study clearly indicates that majority of the children which is $74.66 \%$ falls in the age bracket of $12-14$ years of age who are engaged in doing different economic activities to support their families. The findings of the present study illustrates that economic constraints are there in the way of eradication of child labour; however it is not limited to Pakistan only, other neighbouring and third world countries are also facing the same problem. Due to economic disparity and growing inflation the problem of child labour is increasing day by day which is almost equal to cruelty. Basically, low income families and uneducated parents forced their children to work as lobour in order to earn some money to meet their daily expenditures. Findings of the study also indicates that majority of the child labourers are not getting education due to their low socio-economic status, ignorance of parents and other factors related to poverty which prohibits them in getting education. Article 11 of the Pakistan constitution prohibits slavery and child labour but extreme poverty and hunger forced children to give up their education and indulge in economic activities at very early age to bring food and other daily necessities of life for their family members. An average family size is seven to eight persons and they have to feed them in minimal wage. These children usually lack in nutritional diet and face severe working hazards. They work beyond their capacity; heavy labour not only affects their mental and physical health but also affects their social wellbeing and their overall personalities as well. Many of them fails to achieve their full potential development. Many children throughout the world work to feed their families to overcome the cycle of poverty. The current study statistics show that in child labour boys are in higher ratio as compared to girls. But these results are not the actual facts, as the sector (domestic labour) in which girl child are involved usually hidden from the society. Therefore it is not easy to estimate actual facts and figures of the girl child labourers. It is also noted that Government does not have data about those children who are working in families or are engaged in small businesses. As we have seen that in recent several decades Pakistan's dwelling economy and shrinking industrial sector has adversely affected per capita income and increases poverty. Due to these circumstances parents are forced to use their children as bread earner for their starved families. There is an urgent need to provide broad set of indicators to be used for policy formulation and implementation at various levels.

\section{Recommendations}

Following are the recommendations of this study:

1. Government should introduce effective education system for child labourers so that they can feed their families along with their education

2. State should monitor that no one can exploit children at any level.

3. State should regulate proper laws and policies for health and education of children on priority basis 
4. Work place laws and child protection laws should be implemented so that children especially girls cannot be exploited

5. Hiring rules about minimum age of children should be strictly implemented in order to maintain check and balance system

6. Government should formulate laws which can protect rights of children

7. Raising awareness of the illegitimacy of child labour will also help to curb down this activity. Parents should be made aware that forcing their children to work has legal consequences and that if they are found to assist and support the abuse, then the law will play its part. 